\title{
Transnational Strategies in Higher Education and Cultural Fields: The Case of the United States and Sweden in the 20th Century
}

\section{Dag Blanck and Mikael Börjesson}

Uppsala University

Sweden and the United States occupy very different positions on the transnational market for higher education. Since the middle of the $20^{\text {th }}$ century this market has expanded rapidly, with the U.S. as the dominating country. The new global landscape of higher education has effects on both the national systems of institutions of higher education and on the students taking part in them. In Europe one only has to think of the Bologna Process, which partly can be seen as a reaction to the American dominance, to see the far-reaching influence of international models on national systems. Sweden's position on this market can be described as a peripheral country but still among the central actors. This peripheral position has forced Sweden into a long tradition of peregrinations to mainly European universities, but, in the $20^{\text {th }}$ century, more and more to American institutions of higher learning. In a few areas, Swedish universities are in fact able to compete on this global market, and some of them are among the 100 highest ranked universities in the world.

This special topic of American Studies in Scandinavia ${ }^{1}$ will address a

1 We are pleased that the editors of American Studies in Scandinavia have agreed to this special topic of the journal. We would like to thank all the project participants and the staff and scholars within the research group Sociology of Education and Culture (SEC) (http://wwww.skeptron.uu.se/broady/sec/) at Uppsala University for stimulating and lively discussions, and Michael Nolan of Augustana College, Rock Island, Illinois for close readings of our texts. 
number of questions dealing with the positions of and relationships between Sweden and the U.S. in the sphere of higher education and cultural production. The main issues raised concern the academic migration between the two countries, its volume, nature and organization, as well as the effects of these flows on both persons and ideas. In a sense, we focus on questions of import and export: what is imported, what is exported, and how this changes over time.

\section{Transnational Strategies in Higher Education}

The articles sum up research conducted in the research project Transnational Strategies in Higher Education. Sweden's Relations to France and the U.S., $1919-2009 .^{2}$ The project takes its starting point in the fact that Swedish higher education is no longer so Swedish. Although international links always have been essential for a small peripheral country like Sweden, the internationalization of higher education has definitely entered a new phase during the last two, three decades. Since 1989, the number of students studying abroad has increased tenfold. ${ }^{3}$ And within Sweden, examples from abroad are held up when changes in degrees, courses, and curricula are being considered. All institutions of higher learning are affected by internationalization, and some also enter the competition for prominent positions on a transnational market of education. The substantial educational investments made by Swedish students abroad alter the conditions for entrance to and careers within social fields. In this changing situation, politicians, administrators, teachers, researchers, and students develop new

2 The project is funded by Vetenskapsrådet (The Swedish Research Council) from Jan. 1, 2007 to Dec 31, 2009, and led by Mikael Börjesson. See http://wwww.skeptron.uu.se/transnat/index.htm.

3 At the end of the 1980 s fewer than 2,000 Swedish students studied abroad, whereas in 2002/03 the figure had reached almost 30,000. [Swedish National Agency for Higher Education, Universitet \& högskolor. Högskoleverkets årsrapport 2008, Rapport 2008:19 R, (Stockholm, 2008), p. 36]. The increase was particularly rapid in the 1990 s, when the number of students studying abroad practically doubled every other year There are several explanations for this extraordinary expansion. In 1989 the Swedish government began allowing Swedish students to obtain governmental study loans for study abroad. Three years later, in 1992, Sweden became part of the European Economic Space and joined the Erasmus program for student exchange in Europe. Moreover, in the beginning of the 1990s Sweden suffered a major economic downturn, which held its grip on the country throughout most of the 1990s. As young people found it increasingly difficult to establish themselves on the labor market, the demand for higher education increased. The expansion of Swedish students going abroad can thus be understood as a combination of push and pull effects. In recent years we have seen a slight reduction in numbers, which partly can be explained by the fact that the overall number of applicants to higher education in Sweden has declined. 
and different strategies for defending and advancing their positions. These strategies are the main focus of the project.

The project comprises four areas of studies: 1) Swedish students on the transnational educational market, 2) Transnational assets and the field of elite education in Sweden, 3) Swedish grant holders who go west, and 4) The significance of transnational investments for entrance to and careers within social fields. ${ }^{4}$ Mikael Börjesson's article, an analysis of Swedish students in the Northeastern U.S. in the late 1990s, deals with the first area of research. The article examines their backgrounds and their studies in America, the relationship between the type of institution, the geographic location, and the students' social origin, and how the students' educational gains are related to both location and institution. The articles by Dag Blanck and Andreas Melldahl come from the project's third area of interest and point to the significance of institutions, focusing on the American-Scandinavian Foundation in New York and the Sweden-America Foundation in Stockholm. Blanck shows how different interest groups on both sides of the Atlantic for partly different reasons found common ground in promoting both academic exchange and cultural contacts between Sweden and the United States in the early $20^{\text {th }}$ century. Melldahl's article discusses the SwedenAmerica Foundation Fellowship program in the 1920s and 1930s, its structure and what the fellows studied, particularly emphasizing the distinction between theoretical and practical studies. Bo G. Ekelund's contribution, finally, deals with the fourth area of research, focusing on U.S. cultural flows to and cultural production in Sweden. He discusses the symbolic production of U.S. literature in Sweden from 1980 to 2005, with particular focus on how Swedish critics helped establish Paul Auster as an important author in Sweden and how he was appropriated by critics with different positions in the field.

Our main results emphasize the significance of American higher education for Sweden during the $20^{\text {th }}$ century. Following the end of World War I, the economic, political, cultural, and academic position of the U.S. in the

Methodologically, the project brings together a number of different methods and traditions, and the studies draw on national statistics, a student survey, interviews with students and administrators, and archival materials. Its multidisciplinary nature also assembles scholars from sociology of education, sociology, literature, and history. We argue that our research objectsóflows across national borders of students, scholars, ideas, and other goods, as well as their effects on the national systems and fieldsóneed to be examined in a multidisciplinary fashion. By combining historical perspectives with sociological methods in our studies of different empirical areas, we hope to offer new insights. 
world was successively strengthened. A Swedish re-orientation towards the west took place. The Sweden-America Foundation-with strong financial backing from Swedish industry - and its American sister organization the American-Scandinavian Foundation, were, as both Blanck and Melldahl argue, crucial for establishing academic, technological, and cultural ties with the U.S. As a key actor, the Sweden-America Foundation saw itself acting in a Swedish national interest by ensuring that Sweden could benefit from the growth of technological and scientific knowledge in the U.S.

Börjesson's article shows that at the end of the century, Swedish students were still coming to American institutions of higher learning in significant numbers. They were found in all types of American universities and colleges, with an emphasis on research universities, art schools, and business schools, and targeting the most prestigious institutions. The main conclusion is that social divisions in the distribution of the students according to educational institutions were stronger than according to geographical location. There was a clear overrepresentation of students with large amounts of different types of capitals in Pierre Bourdieu's sense of the term (that is especially economic, cultural, educational and social resources) at the most sought-after and prestigious institutions, while the least competitive and esteemed institutions on the American educational market, such as the community colleges, attracted students with significantly smaller resources. The most resourceful and dominating geographic location, the New York Metropolitan Area, did actually have a larger proportion of students with more modest backgrounds than other areas. Finally, the analysis by Ekelund of the reception of American literature in Sweden points to processes of adaptation and selection as well as to the creation of a separate canon of American authors. These processes of cultural production should thus be read in the light of both domestic factors and of developments in global literary and cultural fields.

\section{National, International, and Transnational}

It is often said that the globalization process weakens nation states. Without going into the large debate on the effects of globalization, we will argue that it is important to acknowledge a number of levels in the analyses of phenomena that cross national borders. They are usually labeled "internationalization," but we would like to reserve the term for situations involving nation states and their representatives, such as agreements between nation states 
on trade, environmental issues, peace operations, etc. Two such examples of international cooperation in education are the Bologna Declaration of 19 June 1999 and NordForsk, the organization for promoting research in the Nordic countries. However, most of the crossings of state borders do not directly involve the states and their representatives, but are rather initiatives taken by individuals, social groups, administrators, and institutions, among others. We label these phenomena 'transnational.'

In reality, however, the borders between national, transnational, and international are often blurred. Education is no exception. For example, when a Swedish student begins to study in the U.S. it is, as we will see, in most cases an individual act, since the studies are organized by the student him- $/$ herself and thus not the result of any exchange agreement between Sweden and the U.S. Still, the Swedish state does influence the impressive number of Swedes studying in the U.S. Since 1989, it has been possible to obtain state support for studies abroad in the form of study loans, an opportunity which large numbers of Swedish students avail themselves of. Thus, in spite of the globalization processes, the Swedish nation state continues to play an important role in the so-called internationalization of higher education in Sweden. In fact, the main bulk of the activities that are brought together under the umbrella of internationalization in one way or another depend on the Swedish state.

Another interesting example of the relations between the national, the international, and the transnational are the organizations like the SwedenAmerica Foundation and the American-Scandinavian Foundations, analyzed by Dag Blanck and Andreas Melldahl in this issue. These foundations were (and still are), on the one hand, private, with private funds and no formal control by the national states. On the other hand, from the beginning they developed a practice and a discourse that were nationalistic in the sense that they both saw to their respective nations' best interests. The transnational links that they supported should help strengthen the nation.

\section{American Influences in Sweden}

The research project and the articles in this issue should also be seen in the larger perspective of Swedish-American relations and in light of the exten- 
sive discussion concerning American influences on the rest of the world in general, and on Sweden in particular. The U.S. plays a significant role in Sweden. ${ }^{6}$ Its influences on Swedish society are many and varied, and it is clearly one of the most prominent points of reference on the Swedish mental map.

The term 'Americanization' is often used in these contexts, but as it carries a normative and frequently pejorative meaning, it is less useful as an analytical concept. ${ }^{7}$ Following the early lead of Rob Kroes, ${ }^{8}$ scholars have paid a great deal of attention to the ways in which American cultural influences have reached and been incorporated in the receiving countries. The process is a complex one in which cerlain influences are accepted, whereas others are not. Although the U.S. as a sending country plays an important role, the receiving countries are not seen merely as passive recipients of cultural influences, but they also play a more active role, and the influences are mediated in different ways. ${ }^{9}$ These adaptations suggest that the American origins are not necessarily immediately noticeable in the receiving countries, and that American ideas change and become domesticated.

The U.S. and its influences on Sweden have been discussed throughout the $20^{\text {th }}$ century. The discussions have dealt with a variety of spheres in Swedish society, but they have been particularly heated in the field of popular culture. ${ }^{10}$ Media historian Ulf Jonas Björk has identified several debates about American popular culture in Sweden during the $20^{\text {th }}$ century,

6 When Swedes who said that they had considered moving abroad in the mid 1990s indicated their preferences, the United States was the most popular destination, named by 20 per cent of the respondents. The U.S. was also a common answer when the question was posed where Swedes would move if political upheavals or other circumstances forced them to. The most popular choice given between 1991 and 1995 was, perhaps not surprisingly, Norway, with between 17 and 32 per cent of the answers. The U.S. was, however, not far behind with between 12 and 32 per cent of the respondents preferring the North American republic, well ahead of Denmark, Australia and Great Britain. (Anna Rönström \& Lennart Weibull, "Världen utanför", in Sören Holmberg \& Lennart Weibull, eds., Mitt i nittiotalet [Göteborg, 1996], p. 415.)

7 Erik Åsard, "Americanization or Globalization? Themes and Topics in a Recurring Debate," in Kerstin Shands et al., eds., Notions of America: Swedish Perspectives (Huddinge, 2004).

8 Rob Kroes, "Americanisation: What are We Talking About?" in Kroes et al., eds., Cultural Transmissions and Receptions: American Mass Culture in Europe (Amsterdam, 1993).

9 Richard Pells, Not Like Us. How Europeans Have Loved, Hated, and Transformed American Culture Since World War II, (New York, 1997); Reinhold Wagnleitner \& Elaine Tyler May, eds. Here, There, and Everywhere. The Foreign Politics of American Popular Culture (Hanover, NH, 2000); Robert Rydell \& Rob Kroes, Buffalo Bill in Bologna. The Americanization of the World, 1869-1922 (Chicago, 2005).

10 The following paragraph is based on Dag Blanck, "Television, Education and the Vietnam War: Sweden and the United States during the Post-War Era" in Alexander Stephan, ed., The Americanization of Europe. Culture, Diplomacy, and Anti-Americanism after 1945 (New York, 2006). 
ranging from dime novels in the 1910 s, American films since the 1920 s, jazz music in the 1920 s and 1930 s, American comic strips in the 1950 s, to American television since the mid 1950s. These so called "moral panic" debates all expressed a fear that Sweden and Swedish culture ran the risk of being overrun by American popular culture, characterized by commercialism, shallowness, and sentimentality. An article from 1996 by a well-known journalist and author provides a fairly typical example, as the author argucs that American culture had descended on Sweden, like a "heavy and slippery blanket" preventing all "spiritual and intellectual development," and that the "masses" were kept "hypnotized" in front of the TV sets, until they fell asleep, "dreaming the American dream, duped by the American myth." There have also been calls for Sweden to defend itself against this attack on the national culture, through rarely implemented restrictions or even a failed 1988 proposal in Parliament for government funding for an inquiry on the negative effects of "Americanization" on Swedish society. ${ }^{12}$

The U.S., its culture, and its influences in and on Sweden in the $20^{\text {th }}$ century have not only been framed in a negative manner. America has also been seen as a model for Sweden, and the American emphasis on economic and individual opportunity and on personal freedom have resonated in Sweden at least since the middle of the $19^{\text {th }}$ century, when they were important factors in explaining the mass migration of Swedes to the U.S. It is also important to underscore that Sweden and the U.S. seem to have found some common ground from the 1930s and on, as the Swedish Social Democrats launched their vision of a different Sweden through the People's Home (folkhemmet), and Franklin D. Roosevelt undertook his reform program in the New Deal. American modernity, with its emphasis on reform and an orientation towards the future, touched upon the modernity of the welfare project of the Swedish Social Democrats. In 1942, for example, Social Democrat Alva Myrdal who had spent several years in the U.S., lectured widely on the topic "The New America" throughout Sweden, arguing that while Europe was bleeding to death "a new world is being shaped in America," with ideals "very much like our own [and]... which are of the greatest

11 Herman Lindqvist, "Hjärntvättade av amerikansk TV," Aftonbladet, 18 February 1996, p. 11.

12 Dag Blanck, "Inte bara McDonald's. Amerika i Europa och i Sverige" in Gunilla Gren-Eklund, ed., Att förstå Europa. Mångfald och sammanhang. Humanistdagarna vid Uppsala universitet 1994 (Uppsala, 1996), p. 219. 
importance to us." ${ }^{13}$ New Dealers, in turn, were also interested in developments in Sweden, as the Social Democrats set out to reform Swedish society, perhaps best expressed in Marquis Childs' 1936 book, Sweden-the Middle Way. ${ }^{14}$

The domestication of American influences in Sweden was made easier by the emphasis on modernity and rationality in the construction of modern Sweden. ${ }^{15}$ The American impulses, which Alva Myrdal encountered during her time in the U.S., were, then, "transplanted" into an already existing Swedish counterpart where they found fertile ground. The movement to reform the Swedish primary and secondary educational systems after World War II is one area in which this transplantation process can be observed, and where Alva Myrdal herself played an important role. ${ }^{16}$

\section{Transatlantic Flows}

Given the central position that the United States has assumed on the transnational market of higher education, the role of higher education and academic migration for American influences in and on the world in general and Sweden in particular deserves more study. A body of literature on foreign students and scholars in the U.S. exists, including significant works on the European academic refugees of the 1930 s and 1940 s, but few attempts have been made to link these to questions of impact and cultural influences. ${ }^{17}$

13 Martin Alm, Americanitis. Amerika som sjukdom eller läkemedel. Svenska berättelser om USA åren 1900-1939, (Lund, 2002), pp. 160-62; Alva Myrdal, Notes for speech "Det nya Amerika" (The New America), October, November \& December 1942, in Alva Myrdal Archives, Arbetarrörelsens arkiv, (Archives of the Swedish Labour Movement), Stockholm.

14 H. Arnold Barton, "The New Deal and the People's Home: American and Swedish Perspectives from the 1930s," in Dag Blanck et al., eds., Migration och mångfald. Essäer om kulturkontakt och minoritetsfrågor tillägnade Harald Rubblom (Uppsala, 1999); Marquis W Childs, SwedenóThe Middle Way (New Haven, CT, 1936).

15 Orvar Löfgren, "Nationella arenor," in Billy Ehn, Jonas Frykman and Orvar Löfgren, Försvenskningen av Sverige. Det nationellas förvandlingar (Stockholm, 1993), pp. 53-65; Jan Olof Nilsson, Alva Myrdal. En virvel i den moderna strömmen (Stockholm, 1994).

16 Dag Blanck, "Television, Education and the Vietnam War",pp. 99-100.

17 On the refugees of the 1930s and 1940s, see Donald Fleming and Bernard Bailyn eds., The Intellectual Migration: Europe and America 1930-1960 (Cambridge, MA., 1968). For a few examples that have linked education with American influences, see Oliver Schmidt "Small Atlantic World: U.S. Philanthropy and the Expanding International Exchange of Scholars after 1945," and Philipp Gassert, "Atlantic Alliances: Cross-Cultural Communication and the 1960s Student Revolution," in Jessica C.E. Gienow-Hecht and Frank Schumacher, eds., Culture and International History (New York, 2003). 
With regard to Sweden, the organizational structure of American higher education has attracted attention. The reform of the Swedish Ph.D. degree in the early 1970 s was strongly influenced by American models, with a government study from 1977 calling it almost a "translation" of the American Ph.D.-degree, ${ }^{18}$ and in 1994 political scientist Olof Ruin noted that the reforms of Swedish higher education during the last quarter of the $20^{\text {th }}$ century constitute "the best example of a conscious 'Americanization' of Swedish society." 19 American models and practices have also been important for the developments of several disciplines in Swedish higher education. American influences have always been strong in the social sciences. Education, economics and business administration are fields where the exchange of persons and ideas has been very lively, and where study trips to America and the use of American textbooks have been very common. Further examples include sociology, which was established in Swedish universities in 1947, and political science. It also seems clear that a period of study in an American university has benefitted the academic careers of these students once they returned to Sweden. ${ }^{20}$

The above examples and the articles on this topic show the significance of studies of the transnational field of higher education for the scholarly discussion about the shaping of American relations with and the American influences on the world. During the $20^{\text {th }}$ century, there has been an intricate pattern of flows of persons and ideas between Sweden and the U.S.; of cultural and educational exports and imports between the two countries. In this exchange, the national has assumed a new significance in the transnational context. To Swedes and to Sweden, investments in American higher education have provided individuals and institutions with possibilities to appropriate the American experiences in Sweden but also in the world beyond their home country. Similarly, American higher education has continued to attract students and scholars from all over the world which clearly has benefitted the American academy and made it even more desirable in the eyes of the rest if the world, while at the same time generating a desire to emulate the American academic success story in the sending countries. In

$18 \mathrm{Li}$ Bennich-Björkman, Learning a Passionate Profession. The Failing of Political Reform in Higher Education. A Swedish Example (Stockholm, 1993), pp. 3-10.

19 Olof Ruin, Amerikabilder. Anteckningar om USA från 50-tal till 90-tal (Stockholm, 1994), p. 228.

20 Franklin Scott, The American Experience of Swedish Students. Retrospect and Aftermath (Minneapolis, 1956), p. 96. 
that way it seems likely that the transnational academic and intellectual interchanges between the U.S. and Sweden will continue, even though Henry Luce's American century has by now been over for close to a decade. 